\title{
Taphonomy, distribution and palaeoecology of stalked barnacles (Crustacea, Cirripedia) from the Bohemian Cretaceous Basin, Czech Republic
}

\author{
Martina Kočová Veselská1, Tomáš Kočíi \\ ${ }^{1}$ Charles University, Institute of Geology and Palaeontology; Albertov 6, CZ-128 43 Prague 2, Czech Republic; \\ e-mail:veselskamartina@gmail.com \\ ${ }^{2}$ Ivančická 581, CZ-199 00 Prague 9-Letňany, Czech Republic; e-mail: protula@seznam.cz \\ (C) 2015 Authors. This is an open access publication, which can be used, distributed and reproduced in any medium according \\ to the Creative Commons CC-BY 4.0 License requiring that the original work has been properly cited.
}

The Cirripedia are marine crustaceans that as adults are usually sessile, attached to hard substrata or to other organisms by their first pair of antennas. The carapace completely envelops the body, and in most forms it secretes a calcareous shell, with an opening where they stretch out for food. Today cirripedes remain a highly successful group of crustaceans, both in number of species and abundance (Newman \& Abbott 1980). The preferred habitats of modern Cirripedia are widely diverse, ranging from the uppermost littoral to abyssal depths. Being principally filter feeders in the intertidal food chain, they modify the habitat structure and affect the abundance and population structure of other intertidal organisms, and are vital to the ecological balance of the nearshore marine system (Chan 2007). However, most Late Mesozoic cirripede genera are extinct which means that, apart from associated faunal elements, there is little except overall capitular morphology that can be used to identify palaeoenvironmental conditions (Buckeridge 1983).

Stalked barnacles most often occur in the fossil record as dissociated plates of capitulum and peduncle, because soon after death plates tend to disarticulate and become scattered, similar to modern lepadids and scalpellids (Hauschke et al. 2011). Whilst certain species of balanids are readily distinguishable from each other in the fossil record, others may easily be confused, especially when preserved as isolated plates. Species-level determination of fossil remains may commonly be achieved by the recognition of either some, or a combination of a few major features of single plates: conical or cylindrical plate, smooth or ribbed surface, shape of growth lines of inner and upper surface, position of apex, etc. (Collins et al. 2014).

The barnacles form a predominant part of the arthropod assemblage throughout

the Bohemian Cretaceous Basin (BCB) and are a common component of the mesofaunal fossil remains of the Upper Cretaceous pelagic and mainly nearshore-shallow marine deposits in the BCB. Barnacles from shallow water deposits possess relatively heavily calcified capitular plates (in comparison to pelagic forms) as an adaptation to high-energy environment. However, they could inhabit also microenvironments behind larger boulders, where the water current is not so turbulent. Although most of these cirripede shells involved rapidly break down into separate plates or valves after death, species of the Cretaceous genus Stramentum Logan provides some notable exceptions. Under certain conditions, individual plates of heavily calcified stramentids have remained articulated during fossilization and their occurrence appears to be restricted to three exceptional 
circumstances: when their cypris larvae attached directly to a substrate (e. g. ammonite shells); when cirripedes were embedded in black shales; or when cirripedes were rapidly buried. All Czech stramentids are known only as epizoans of the body chamber of smooth planispiral ammonites with widely spaced, shallow ribs, such as Collignoniceras Breistroffer and Lewesiceras Spath (Kočová Veselská et al. 2013). In addition, one articulated capitulum of Arcoscalpellum angustatum (Geinitz) is documented from the BCB; only a few reports of complete Arcoscalpellum are known from the Cretaceous deposits.

The predation on cirripedes is also known from the BCB. The penetrative holes and non-pentrative pits of ichnogenus Sedilichnus Müller, caused by carnivorous naticid and muricid gastropods, are present on two capitular plates of Cretiscalpellum glabrum (Roemer). Microborings, which are more abundant on capitular cirripede plates from the $\mathrm{BCB}$, are developed as small connected channels and could be caused by algae, hydroids, fungi or even clionid sponges. Similar data of predation on cirripede valves are poorly known, e. g. from the Campanian locality Ivö Klack in southern Sweden (Gale \& Sørensen 2015).

\section{REFERENCES}

Buckeridge J.S., 1983. Fossil barnacles (Cirripedia: Thoracica) of New Zealand and Australia. New Zealand Geological Survey Paleontological Bulletin, 50, 1-151.

Chan B.K.K., 2007. Ecology and biodiversity of rocky intertidal barnacles along a latitudinal gradient; Japan, Taiwan and Hong Kong. Publications of the Seto Marine Laboratory, Special Series: Selected papers of the Nagisa World Congress 2006, Kyoto University Press, Kyoto, 1-10.

Collins J.S.H., Donovan S.K. \& Mellish C., 2014. An illustrated guide to the fossil barnacles (Cirripedia) from the Crags (Plio-Pleistocene) of East Anglia. Proceedings of the Geologists' Association, 125, 215-226.

Gale A.S. \& Sørensen A.M., 2015. Taxonomy and palaeoecology of thoracican cirripedes (Crustacea) from a Campanian rocky shoreline at Ivö Klack, southern Sweden. Cretaceous Research, 54, 212-242.

Hauschke N., Schöllmann L. \& Keupp H., 2011. Oriented attachment of a stalked cirripede on an orthoconic heteromorph ammonite - implications for the swimming position of the latter. Neues Jahrbuch für Geologie und Paläontologie, 262, 2, 199-212.

Kočová Veselská M., Kočí T. \& Buckeridge J., 2013. A systematic revision of Stramentum (Stramentum) pulchellum (G.B. Sowerby Jr., 1843) (Cirripedia, Thoracica, Stramentidae) from the Bohemian Cretaceous Basin, the Czech Republic. Acta Musei Nationalis Pragae, Series B Historia Naturalis, 69, 34, 151-158.

Newman W.A. \& Abbott D.P., 1980. Cirripedia: stalked barnacles. [in:] Morris R.H. (ed.), Intertidal invertebrates of California, Stanford University Press, California, 504-535. 